\title{
Investigation of the Feasibility of an Amide-based Prodrug Under Physiological Conditions
}

\author{
Arnab De $\cdot$ Richard D. DiMarchi
}

Published online: 24 September 2008

(C) Springer Science+Business Media, LLC 2008

Erratum to: Int J Pept Res Ther

DOI 10.1007/s10989-008-9141-4

Due to a publication error the word "feasibility" was misspelled in the article title.

The online version of the original article can be found under doi:10.1007/s10989-008-9141-4.

A. De - R. D. DiMarchi $(\bowtie)$

Department of Chemistry, Indiana University,

Bloomington, IN 47405, USA

e-mail: rdimarch@indiana.edu

A. De

e-mail: arde@indiana.edu 